Романів Оксана Яківна кандидат географічних наук, доцент, завідувач кафедри геології та гідрології, Національний університет водного господарства та природокористування, вул. Соборна, 11, м. Рівне, 33028, тел.: (0362) 633-209, e-mail: o.ia.romaniv@ nuwm.edu.ua, https://orcid.org/0000-0002-2870-1322

Скабара Роман Михайлович кандидат географічних наук, доцент, доцент кафедри спортивного туризму, Львівський державний університет фізичної культури імені Івана Боберського, вул. Тадеуша Костюшка, 11, м. Львів, 79000, тел.: (0322) 553-208, e-mail: borakuda1974@gmail.com, https://orcid.org/0000-00032984-3135

\title{
КОНЦЕПТУАЛЬНІ ЗАСАДИ СТРАТЕГІЇ РОЗВИТКУ МЕДИЧНОГО ТУРИЗМУ В УКРАЇНI
}

Анотація. У статті досліджено вплив ключових детермінант на розвиток глобального ринку медичного туризму. Україна, маючи репутацію постачальника медичних послуг 3 хорошим співвідношенням ціна-якість, може стати перспективним напрямком розвитку медичного туризму в світі. Факторами залучення в Україну потенційних зарубіжних пацієнтів можуть слугувати:

- висока якість медичних послуг, зокрема репродуктивні технології, стоматологія, ортопедія та інші медичні напрями лікування;

- висококваліфіковані фахівці;

- високоефективні технології та методики лікування, які не мають аналогів за кордоном;

- комфортні природні умови України, які створюють унікальні можливості для медичного туризму;

- заходи з інформатизації та просування як медичних послуг, так й іміджу України.

Для збільшення частки в’їзного медичного туризму України необхідно враховувати стан розвитку окремих галузей медицини, вартість діагностики та лікування у країнах-конкурентах, законодавче регулювання. Важливими чинниками $\epsilon$ стан транспортної та готельної індустрії, рівень володіння іноземними мовами. Але найбільш вагомим аргументом при виборі країни для лікування чи діагностики є іiї бренд. Україні доведеться пройти ще чималий шлях для розвитку свого позитивного іміджу у сфері медичного туризму. 3 боку 
державної влади та органів місцевого самоврядування доцільним є протекціонізм, що повинен мати своє вираження у системі преференцій, у пільговому оподаткуванні та у наданні фінансово-кредитних стимулів для нарощення i використання потенціалу медичного туризму в Україні.

У статті окреслено основні проблеми в сфері медичного туризму України. Використання наведеного переліку проблем дозволяє системно їх ураховувати під час розробки та реалізації заходів, спрямованих на покращання ситуації у цій cфepi.

Перспективи подальшого розвитку медичного туризму в Україні виглядають цілком оптимістичними, але лише за умови консолідації сил і ресурсів усіх зацікавлених осіб.

Ключові слова: медичний туризм, детермінанти розвитку, туристична дестинація, медичні послуги, туристичний потік, ринок туризму

Romaniv Oksana Yakivna Candidate of Geographical Sciences, Associate Professor, head of the department of geology and hydrology, University of Water Management and Environmental Engineering, Soborna St., 11, Rivne, 33028, tel.: (0362) 633-209, e-mail: o.ia.romaniv@ nuwm.edu.ua, https://orcid.org/0000-0002-2870-1322

Skabara Roman Mykhaylovych Candidate of Geographical Sciences, Associate Professor, associate professor of the department of sports tourism, Lviv State University of Physical Culture, T. Kostiushka St., 11, Lviv, 79000, tel.: (0322) 553 208, e-mail: borakuda1974@gmail.com, https://orcid.org/0000-0003-2984-3135

\section{CONCEPTUAL FUNDAMENTALS OF MEDICAL TOURISM DEVELOPMENT STRATEGY IN UKRAINE}

Abstract. The article examines the impact of key determinants on the development of the global medical tourism market. Ukraine can become a promising destination for medical tourism in the world, because it has a reputation as a provider of medical services with a good value for money. Factors for attracting potential foreign patients to Ukraine may be:

- high quality of medical services, including reproductive technologies, dentistry, orthopedics and other medical treatments;

- highly qualified specialists;

- highly effective technologies and methods of treatment that have no analogues abroad;

- comfortable natural conditions of Ukraine, which create unique opportunities for medical tourism; 
- measures for informatization and promotion of medical services and image of Ukraine.

The goal is to increase the share of inbound medical tourism in Ukraine. It is necessary to pay attention to the state of development of certain branches of medicine, the cost of diagnosis and treatment in competing countries, the legislative regulation. Important factors are the state of the transport and hotel industry, the level of knowledge of foreign languages. But the most compelling argument when choosing a country for treatment or diagnosis is its brand. Ukraine still has a long way to go to develop its positive image in the field of medical tourism. Protectionism on the part of state authorities and local self-government bodies is expedient. Such protectionism should be manifested in the system of preferences, in preferential taxation and in the provision of financial and credit incentives for building and using the potential of medical tourism in Ukraine. The article outlines the main problems in the field of medical tourism in Ukraine. The use of the given list of problems allows to use them systematically during the development and implementation of measures aimed at improving the situation in this area.

Prospects for further development of medical tourism in Ukraine look quite optimistic, but only when the forces and resources of all stakeholders can be consolidated.

Keywords: medical tourism, determinants of development, destination, medical services, tourist flow, tourism market

Постановка проблеми. Ринок медичного туризму за кордоном має тенденцію до зростання, оскільки це конкурентоспроможний i високоприбутковий сегмент світового ринку послуг. А тому стратегічна інтеграція регіонів України з високим потенціалом розвитку медико-туристичних послуг в глобальну туристичну систему є закономірною необхідністю.

Аналіз останніх досліджень i публікацій. Узагальнення публікацій науковців, у тому числі Діденко К.Д. та Жученко В.Г. [2], Сисоєнко І. [3], Удовиченко Н.M. [4] та інших, результати власних досліджень за даною тематикою дозволили виділити проблеми розвитку медичного туризму в Україні, на які необхідно звернути увагу впродовж найближчих років:

1. Загальні проблеми: брак злагодженої співпраці органів державного управління, органів місцевого самоврядування, суб’єктів туристичної індустрії та медичних закладів усіх форм власності.

2. Складна геополітична, економічна, соціальна ситуації в країні: анексія Криму та військові дії на Донбасі; стагнація української економіки; погано контрольовані інфляція та зміна курсу національної валюти; масштабна бідність, старіння населення, підвищення загального рівня його захворюваності (у т.ч. 
поширення патологій та хронічних хвороб).

3. Проблеми у сфері охорони здоров'я: відсутність державної підтримки тих iii сегментів, котрі здатні забезпечити істотний позитивний ефект; жорстке адміністрування й втручання у внутрішньогосподарську діяльність медичних закладів; недостатне і нераціональне їх бюджетне фінансування; недосконалість економічних і правових механізмів публічного управління щодо розширення асортименту, збільшення обсягів і підвищення якості платних медичних послуг; орієнтування населення на «безоплатну» медицину; слабка розвиненість системи медичного страхування; територіальні диспропорції доступу населення до необхідних медичних послуг (у т.ч. відсутність та/чи закриття медичних закладів у невеликих населених пунктах).

4. У сфері медичного туризму: відсутність комплексного бачення країни як перспективної туристичної дестинації, а також ефективної стратегії розвитку цієї сфери як на національному, так i на регіональному рівнях; інституційноорганізаційна система вітчизняної індустрії туризму знаходиться в стадії перманентного реформування; недостатність державної підтримки розвитку медичного туризму; орієнтація туристичних фірм в ціноутворенні не на ринковий попит, а на витратний підхід при формуванні турпродуктів; невідповідність більшості лікувальних і курортних закладів міжнародним стандартам; низькі темпи модернізації застарілої лікувальної, курортно-рекреаційної та туристичної інфраструктури, незначні обсяги залучення інвестицій у їх розвиток; невисокий рівень маркетингових досліджень у сфері медичного туризму, дефіцит інформаційно-рекламного забезпечення на внутрішньому i, особливо, зовнішньому ринках; невідповідність наявної туристичної інфраструктури світовому рівню та сучасним вимогам споживачів туристичного продукту; занадто складні, порівняно із загальновизнаною міжнародною практикою, візові, митні та прикордонні процедури; недостатне використання прогресивного світового досвіду у царині медичного туризму.

Означений перелік проблем не $\epsilon$ вичерпним, але i не $\epsilon$ таким, котрий «перекреслює» перспективи розвитку медичного туризму в Україні. Радше за все, мова йде про формування плану дій, спрямованих спочатку на мінімізацію негативних ефектів унаслідок впливу наявних проблем, а потім - на забезпечення сталих темпів розвитку медичного туризму.

Мета статті - окреслення концептуальних основ для формування стратегії розвитку України як конкурентоспроможної дестинації на глобальному ринку медичного туризму.

Виклад основного матеріалу. Чинниками перспективності будь-якої країни для медичного туризму розглядають традиційно такі:

- рівень розвитку медицини, медичних технологій тощо; 
- вартість діагностики та лікування;

- розвиток транспортного та готельного секторів;

- рівень мовної інтеграції в країні;

- законодавча база;

- імідж держави;

- локалізація країни на мапі світу.

На основі проведеного огляду наукових джерел та на підставі власних досліджень, приходимо до узагальнення, що в медичному туризмі ключовими детермінантами, які забезпечують розвиток туристичних дестинацій-лідерів глобального масштабу, вважають такі:

- вигідне географічне розташування туристичної дестинації;

- розвинена транспортна і сервісна інфраструктура туристичної дестинації, що відповідає міжнародним стандартам;

- наявність у туристичній дестинації визначних і цікавих туристичних осередків, можливостей організації індивідуальних туристичних маршрутів 3 врахуванням стану здоров'я споживача медичних послуг;

- відносно невисока оплата праці населення туристичної дестинації, зокрема, на ринку медичного туризму;

- мінімальні бюрократичні, адміністративні та візові перепони для доступу на ринок медичного туризму іноземних учасників;

- збалансоване поєднання в діяльності закладів медико-туристичної сфери найбільш поширених медичних послуг (стоматологія, пластична хірургія, ортопедія, кардіолікування) з певними спеціалізованими і рідкісними сервісними послугами (бонусні SPA-процедури, акцент на сімейному відпочинку тощо);

- відповідність закладів, що функціонують на ринку медичного туризму дестинації, міжнародним стандартам якості шляхом проходження $\mathrm{i}$ підтвердження акредитації (JCI, TAS тощо);

- високий потенціал туристичної дестинації щодо висококваліфікованих медичних фахівців (навчання або стажування за кордоном, володіння іноземними мовами, успішна медична практика за рахунок застосування інноваційних медичних технологій тощо);

- чітке законодавче та нормативно-правове підгрунтя для усіх видів діяльності суб'єктів ринку медичного туризму;

- максимально своєчасне та достовірне інформаційне забезпечення щодо діяльності (спеціалізації, рівня кваліфікації персоналу, умов і вартості надання послуг тощо) суб'єктів ринку медичного туризму дестинації; комфортні засоби зв'язку для потенційних споживачів медико-туристичних послуг, зокрема, через он-лайн сервіси мережі Інтернет (інформування, анкетування, віртуальне консультування, попередній запис тощо); 
- функціонування закладів на ринку медичного туризму дестинації за принципом реінжинірингу, тобто «неперервного їх розвитку як системи в процесі надання комплексу послуг i просуванні нових напрямів діяльності шляхом розширення і модернізації наявних послуг, їх інформаційного забезпечення та удосконалення» [1];

- загальне позитивне політичне і соціально-економічне середовище в країні та іiі регіонах-осередках медичного туризму;

- доступність фінансово-кредитних банківських послуг тощо.

Проте неоднозначно діють ці детермінанти на розвиток туристичних дестинацій медичного туризму. Адже сьогодні, не залежно від наявності тих чи інших факторів, існують ще й інші передумови, які роблять медичні подорожі успішними проектами для дестинацій різного масштабу - від локальних до національних. Щонайменше 50\% країн світу нині конкурують на ринку медикотуристичних послуг. I як в будь-якому виді бізнесу, конкуренція відіграє тут чималу роль. I не вигідне географічне положення є в даному випадку головною конкурентною перевагою. Оскільки практично будь-яка європейська країна в такому випадку могла би претендувати лише за рахунок цього чинника на лідерство. Проте, в сучасних мовах, коли завдяки розвитку транспортних технологій ведеться мова про так званий феномен «смерті відстані», вигідне географічне положення взагалі не має явних переваг і зводить усі країни у відносно однакове становище.

Фактор розвитку спеціалізованих сервісних інфраструктур своєрідно впливає на формування географії світових туристичних потоків медичного туризму. Наприклад, i азійські, і європейські країни розглядають африканський ринок як потенційне джерело туристів-пацієнтів, оскільки медична інфраструктура на континенті слабо розвинена. Але країни-конкуренти із Близького Сходу, Азії та Свропи не докладають достатніх зусиль для того, щоб стати більш привабливими для жителів Африки. Deloitte Research зазначає ще й такі переважаючі глобальні рухи пацієнтів: Індія надає пацієнтам із США, СС, Канади та Китаю медичні послуги у сфері кардіологічних та ортопедичних процедур; Південна Корея надає китайським та японським пацієнтам послуги 3 хірургічного втручання на хребті, онкологічні обстеження, комплексні огляди здоров'я, косметичні операції; Малайзія відома тим, що пропонує спеціальне лікування опіків, пакети оглядів фертильності для мешканців країн АСЕАН та Близького Сходу; Таїланд пропонує комплексні медичні огляди та косметичні операції для пацієнтів Японії, Китаю, В’єтнаму, Кореї, Китаю та Близького Сходу; Туреччина пропонує офтальмологію, репродуктологію та косметологічні послуги європейським пацієнтам [8].

Мексику, Південну Америку відвідують пацієнти із США та Канади, які 
мандрують $з$ метою пошуку медичних послуг пластичної хірургії та загального огляду здоров'я. Та не менш важливим для даного регіону світу є те, що ринок медичного туризму США користується попитом у еліти. Ціни за послуги можуть бути в даному випадку надзвичайно високими, проте країну відвідують знаменитості, високопоставлені особи, а також усі, хто хоче отримати найкраще лікування у відомих медичних установах. Якісні послуги затребувані тут за будьякою ціною. Отже, в даному випадку фактор низьких цін втрачає свою роль.

Таким чином, прояв зазначених вище нами ключових детермінант розвитку медичного туризму допускає можливість їх різного тлумачення. Для дестинацій медичного туризму вони мають свою регіональну специфіку, хоча ринок медичного туризму i $є$ глобалізованим. При цьому на даному ринку вже сформовані означені нами вище напрями руху туристичних потоків пацієнтів. I $\epsilon$ окреслене коло національних туристичних дестинацій-лідерів у медичному туризмі.

Одні 3 детермінант 3 плином часу втрачають свою вагомість. А натомість з'являються нові фактори розвитку. Проте, щоб стати лідером на світовому ринку медичного туризму, безперечно потрібна державна підтримка цієї сфери діяльності. Це засвідчує досвід багатьох країн світу.

Наприклад, в Ізраїлі чи Туреччині в галузь вкладаються кошти держави та інвесторів. Там залученням пацієнтів займаються спеціальні агентства, фінансується промоушен і реклама.

У понад 50-ти країнах світу в рамках розвитку своїх економік прийняті національні програми з медичного туризму. Україні на це поки що можна лише сподіватись. Державі потрібно розробити якісні програми з підтримки медичного туризму, ось тоді і вітчизняна медицина, і бюджет зможуть відчути результат, який, до речі, може обчислюватися мільйонами доларів прибутку.

Наприклад, Туреччина щороку отримує від медичного туризму в середньому 2,5 мільярди доларів. За прогнозами експертів, обсяг ринку Індії до кінця наступного десятиліття досягне 1,9 мільярда доларів. У Південній Кореї прибуток галузі за 2015 рік склав близько 160 мільйонів доларів. А за останні 6 років кількість медтуристів зросла на 33\%. Урядом щорічно виділяється понад 4 мільйони доларів на популяризацію галузі медичного туризму. Можливості медичного туризму оцінили і найближчі сусіди України, зокрема Білорусь. У 2014 році країну відвідало понад 160 тисяч іноземних пацієнтів. На лікування до Білорусі приїжджають громадяни з понад 70 країн світу [3].

Отже, до основних інструментів, що використовуються на практиці державної підтримки ринку медичного туризму за кордоном, слід віднести: адміністративні (сертифікація, акредитація, стандартизація, візові процедури); законодавчо-правові (нормативно-правові акти та документи, що регламентують 
діяльність суб’єктів ринку); фінансові (податкові, кредитні, митні, інвестиційні, тарифні важелі).

Варто наголосити, що навіть за умов відсутності прямої фінансової підтримки суб'єктів або інфраструктурних об’єктів ринку медичного туризму, державним структурам у цій сфері слід здійснювати широкомасштабну інформаційну підтримку шляхом формування чітких державних програм зі зміцнення іміджу країни, створення та просування ऑii туристичного бренду 3 акцентами на унікальності і перевагах медичного туризму в окремих регіонах країни (як це відбувається у Німеччині, Ізраїлі, Індії тощо). Необхідністю є також окреслення i контроль ключових вимог до безпеки медичних туристів та дотримання відповідальності за результати лікування. Лише тоді потік медичних туристів матиме тенденцію до зростання як в міжрегіональному, так i в міждержавному вимірі.

Щоб Україна мала змогу стати на рівні з країнами-лідерами глобального ринку медичного туризму і позиціонувати себе як успішну медико-туристичну дестинацію, країні слід добре знати своїх конкурентів і вміти диференціюватися від них, пропонуючи різноманітні якісні послуги, та вкладати ресурси в брендинг і маркетинг.

I. Гева висунув теорію 20/50 [8], оцінюючи перспективи медичного туризму у світі. На його думку, ринок медичних подорожей не буде швидко розширюватися. Він досягне певного рівня, a, разом 3 тим, зміниться співвідношення попиту та пропозиції. Загальна кількість країн, які претендують на надання медичних послуг мандрівникам, в кращому випадку скоротиться до 50 впродовж 5 років. А ті країни, які досі ще не вийшли на цей ринок, або не інвестують в цю сферу належних коштів, 3 ринку підуть. Ці 50 країн будуть поділені на дві основні групи:

1. Перша група - «Прем'єр-ліга» - включатиме не більше 20 країн, у тому числі уже згадані вище розвинені національні туристичні дестинації медичного туризму та кілька інших, які на даний час набирають обертів. Ці країни пропонуватимуть інноваційні, унікальні послуги не лише в галузі медицини, а й у всіх інших сферах гостинності.

2. Друга група включатиме, в кращому випадку, 30 інших країн, які можуть запропонувати прийнятні медичні послуги 3 пропозиціями гостинності, але на нижчому рівні якості за нижчу ціну.

За прогнозами I. Гева [8], у інших країнах, де зараз надаються послуги медичного туризму, увага буде зосереджена на розвитку внутрішнього туристичного продукту, орієнтованого на своє власне населення.

На наш погляд Україна має всі шанси увійти до першої групи країн, які згідно своєї теорії 20/50 виокремив І. Гева. 
Діяльність лікарень та клінік, які визначили для себе медичний туризм переважаючим напрямом розвитку, дедалі більше має координуватися на національному та субнаціональному рівнях. Таким чином буде досягнута така мета: цілі міста, регіони та врешті й країна отримають визнання так званих терапевтичних ландшафтів - медико-туристичних дестинацій відповідної спеціалізації. Розвиток та популяризація медичного туризму в різних частинах світу, як-от Індія, Йорданія, Малайзія, Об'єднані Арабські Емірати, Південна Корея, Сінгапур, Таїланд, Філіппіни, Ямайка, Японія спиралися на подібні підходи. Уряди цих країн зосереджуються на лібералізації секторів охорони здоров’я, дозволяючи медичним установам отримувати фінансовий прибуток від догляду за пацієнтами, заохочуючи прямі іноземні інвестиції у охорону здоров'я та послаблюючи обмеження на рекламу медичної допомоги. Державна влада регулює імміграційний та в’їний режим для задоволення особливих потреб пацієнтів (наприклад, забезпечує багаторазові візи, триваліші перебування, візи для супроводжуючих осіб, швидке обслуговування на пунктах пропуску туристів тощо). Медичні заклади також можуть скористатися низкою фінансових стимулів та спеціальних грантів. Також зусилля спрямовуються на наданням допомоги у отриманні національно та міжнародно визнаної акредитації для приватних i державних закладів охорони здоров’я, а ще - на забезпечення того, щоб і медичні працівники, i медичні туристичні агенти мали належну підготовку та кваліфікацію. Цей міжнародний досвід, який зарекомендував себе як результативний, варто запозичити й Україні.

Україна вже зробила серйозні кроки у напрямку піднесення медичного туризму. Першим поступом стало створення Української Асоціації медичного туризму, яка взяла на себе місію в об'єднанні ресурсів державного та приватного сектора медицини України.

Виокремлення медичного туризму не знайшло, на жаль, відображення в законодавчому полі України, однак Всесвітньою організацією 3 туризму (World Tourism Organization), яка є провідною міжнародною організацією у цій сфері, медичний туризм визначено як одну з провідних моделей туристичного руху.

Цільовим орієнтиром розвитку медичного туризму в Україні є насамперед залучення закордонних туристів, приплив яких акумулює значні вхідні фінансові потоки. Україна має високий потенціал медичних, оздоровчих і рекреаційних ресурсів та конкурентні переваги за ціновими параметрами, що може посприяти країні стати одним із світових лідерів з медичного в’ізного туризму.

Основними напрямами в`їзного медичного туризму в Україні $є$ надання медичних послуг з таких спеціальностей: репродуктивна медицина; стоматологія; офтальмологія; кардіологія; естетична медицина та косметологія; пластична хірургія; санаторно-курортне лікування; клітинна інженерія, в т.ч. використання 
банку пуповинної крові [5].

На сьогодні в Україні на сучасному рівні, 3 використанням принципів доказової медицини, в рамках в'їзного медичного туризму надають медичні послуги Київський міський Центр серця, Центр дитячої кардіохірургії, Інститут клітинної терапії, Міжнародний Центр Біотехнологій «Біостем», Клініка «ЕМСЕЛЛ», кілька онкологічних клінік (ЛІСОД, Інновація, Кібер-клініка Спіженко), приватні багатопрофільні лікувально-профілактичні заклади, клініки клітинної терапії, включаючи кріобанки. За оцінками компанії «МедЕкспрес», у нашій країні працює приблизно 50-70 медичних центрів, орієнтованих на клієнтів-іноземців [2].

Серед основних переваг лікування в Україні можна виокремити високу якість послуг в поєднанні з невисокою вартістю лікування та відсутність черги на лікування. Додатковими перевагами для розвитку в'їзного медичного туризму в Україні $\epsilon$ укомплектованість сучасною медичною технікою спеціалізованих та приватних лікувально-профілактичних закладів, безвізовий режим для багатьох країн.

Важливо, що в Україні нині існує сприятлива законодавча база в сфері репродуктивного здоров'я та клітинної терапії, що в синергізмі з сучасним обладнанням клінік і високим професіоналізмом лікарів призводить до значної зацікавленості іноземців в отриманні медичних послуг саме в Україні. Також ми бачимо зацікавленість міжнародних медичних пацієнтів в отриманні допомоги в приватних онкологічних клініках України. Це пов'язано з тим, що в багатьох країнах ця галузь медицини знаходиться тільки в державному секторі, що не завжди передбачає персоналізований підхід.

Далеко не останню роль в ухваленні рішення про лікування за кордоном відіграє рівень сервісу та відсутність мовного бар'єру. У цих аспектах Україна теж просунулася в позитивному напрямку. Багато лікарів володіють іноземними мовами, а в клініках, які приймають зарубіжних пацієнтів, це норма і для середнього медперсоналу. Здебільшого це стосується англійської мови. Щодо російськомовних пацієнтів, то навіть у санаторіях і реабілітаційних центрах України кожен співробітник володіє російською мовою на високому рівні. А у закладах Західної України також можна почути польську та угорську мови [2].

Отже, українські клініки стрімко заробляють популярність на ринку світового медичного туризму. За висновками Хрущ Ю.М. та Діоба К.І., лікування в Україні стає все більш популярним серед пацієнтів із Західної Європи, США, Ізраїлю, Великобританії [6].

Водночас має місце і виїзний медичний туризм в Україні. За даними Української асоціації медичного туризму [5] структура послуг виїзного медичного туризму складає: $40 \%$ - лікування; $30 \%$ - оздоровлення; $25 \%$ - 
діагностика; 5\% - медичне туристичне страхування.

Основні напрями виїзного медичного туризму за кордон такі:

- онкологія (Ізраїль, Туреччина, Німеччина, Австрія);

- кардіологія, складні операції на серці (Швейцарія, Японія, Ізраїль, Туреччина, Німеччина);

- офтальмологія (Туреччина);

- пологи (США, Німеччина);

- пластична хірургія (США, Швейцарія, Австрія);

- діагностика організму (Ізраїль, Німеччина, Швейцарія, Японія) [9].

Найбільш популярні країни серед українців для лікування за кордоном Ізраїль, Німеччина, Швейцарія, Туреччина. Перспективні напрями - Італія, Австрія, Сінгапур. Проте для українців найбільш прийнятною країною 3 точки зору усіх факторів (місце розташування, вартість, візова підтримка) є Туреччина. Що ще приваблює наших співвітчизників у цій країні? Бути дешевшою, ніж європейські країни - не єдина причина вибору Туреччини. Наприклад, одна 3 причин, чому люди обирають Туреччину для екстракорпорального запліднення, полягає в тому, що коефіцієнт успіху в Туреччині з першої спроби вищий, ніж у європейських країнах. А ще один з приладів в онкології, що використовується лише у п'яти країнах Європи, доступний і в Туреччині, яка досягла значного прогресу у дослідженнях та лікуванні раку. Таким чином, іноземні пацієнти отримують можливість лікуватися за допомогою послуг світового класу та одночасно відпочивати [7].

Ринок виїзного медичного туризму в Україні структурований за такими виробниками-посередниками послуг:

- національні туристичні підприємства. Переважна більшість туристичних компаній України розглядає медичний туризм як один із видів свого бізнесу, проте тільки невелика їх кількість спеціалізується на цьому виді туристичної діяльності;

- лікувально-профілактичні заклади, які пропонують організацію медичної допомоги за кордоном, як додатковий вид послуг. Наприклад, Медична компанія «Клініка Гіппократ» 3 окремим структурним підрозділом медичного туризму «Гіппократ ІнтерМедСервіс Ассистанс», медична мережа «Добробут»;

- іноземні медичні заклади, які пропонують свої послуги для громадян України;

- закордонні немедичні заклади, які мають свої представництва або посередників в Україні. Наприклад, з 2012 року на території України функціонує ТНТС-Україна, що є офіційним представником Турецької асоціації медичного туризму [2].

Крім того, в Україні розвивається не тільки міжнародний, але і внутрішній 
медичний туризм - між регіонами України.

Отже, медичний туризм є перспективним сегментом туристичного ринку України. Але сьогодні він в Україні розвинутий ще слабко. Поки що Україна не може якісно конкурувати на світовому ринку. I перешкодами, на жаль, є фактори державного регулювання та нестійка політична ситуація в країні. Держава зволікає зі створенням правової бази та правового забезпечення, не говорячи про політику фінансової і соціальної підтримки. Політична ситуація провокує ризики особистої безпеки пацієнтів через військовий конфлікт. 3 іншого боку, останній фактор формує в нашій країні цільовий сегмент - реабілітацію військовослужбовців та постраждалих від військового конфлікту. Незважаючи на усі проблеми і перешкоди інвестиційний потенціал в Україні значний: вітчизняний ринок, володіючи рекреаційними, ціновими та фаховокомпетентними перевагами, здатен формувати якісний сервісний медичний туристичний продукт.

Висновки. В Україні медичний туризм перебуває на етапі становлення. В країні наявні усі види ресурсів, необхідні для розвитку медичного туризму: фахівці зі світовим ім'ям різних профілів; сучасні методики діагностики, лікування та реабілітації; медичні заклади з розвиненою матеріально-технічною базою; курорти міжнародного значення; привабливе співвідношення «ціна якість» на медичні послуги тощо.

Отже, факторами залучення в Україну потенційних зарубіжних (та й українських) пацієнтів можуть слугувати:

- висока якість медичних послуг у поєднанні з низькою вартістю, зокрема репродуктивні технології, стоматологія, ортопедія та інші медичні напрями лікування за конкурентоспроможною ціною і високою якістю;

- висококваліфіковані фахівці;

- високоефективні технології та методики лікування, які не мають аналогів за кордоном;

- природні, кліматичні умови України, які створюють унікальні можливості для медичного туризму;

- заходи $з$ інформатизації та просування як медичних послуг, так й іміджу України.

Для збільшення частки в’їзного медичного туризму України необхідно враховувати стан розвитку окремих галузей медицини, вартість діагностики та лікування у різних країнах, законодавче регулювання. Важливими чинниками $є$ стан транспортної та готельної індустрії, рівень володіння іноземними мовами. Але найбільш вагомим аргументом при виборі країни для лікування чи діагностики $є$ те, як сприймається їі бренд. Україні як державі, що активно інтегрується у міжнародні структури, доведеться пройти ще чималий шлях для 
розвитку свого позитивного іміджу у сфері медичного туризму.

3 боку державної влади та органів місцевого самоврядування доцільним $є$ певний протекціонізм, що матиме своє вираження у системі преференцій, пільговому оподаткуванні i наданні фінансово-кредитних стимулів для нарощення і використання потенціалу медичного туризму в Україні.

Використання наведеного переліку проблем розвитку медичного туризму в Україні дозволяє системно їх ураховувати під час розробки та реалізації заходів, спрямованих на покращання ситуації у цій сфері.

Перспективи подальшого розвитку медичного туризму в Україні виглядають цілком оптимістичними, але лише за умови консолідації сил і ресурсів усіх зацікавлених осіб. Україна, маючи репутацію постачальника медичних послуг 3 хорошим співвідношенням ціна-якість, може стати перспективним напрямком розвитку медичного туризму в Свропі та світі. Продовження наукових розвідок за даною проблематикою сприятиме подальшому розвитку медичного туризму.

\section{Jimepamypa:}

1. Вахович I.M. Фактори розвитку регіонального ринку медичного туризму в розвинених країнах світу. URL : http://www.hitt-cis.net/wp-content/uploads/2010/11/HITT/Ukraine. (дата звернення: 25.07.2020).

2. Діденко К.Д., Жученко В.Г. Медичний туризм в Україні: сучасний стан та перспективи розвитку. Науковий вісник Херсонського державного університету. Серія «Економічні науки». Випуск 16. Частина 4. 2016. С. 101-105.

3. Сисоєнко Ірина. Як медичний туризм допоможе врятувати економіку України. URL : https://life.pravda.com.ua/columns/2016/04/12/210925/. (дата звернення: 18.07.2019).

4. Удовиченко Н. М., Мельниченко О. А. Медичний туризм: сутність і види. Соціальноекономічний $i$ гуманітарний виміри розвитку торгівлі, готельно-ресторанного та туристичного бізнесу: зб. тез доп. міжнар. наук.-практ. конф., 23-24 березня 2017 р. Харків: Вид-во ХТЕІ КНТЕУ, 2017. С. 185-186.

5. Українська асоціація медичного туризму. URL : http://uamt.org.ua/UA/. (дата звернення: 15.08.2021).

6. Хрущ Ю.М., Діоба К.І. Особливості розвитку медичного туризму в світі. Історикогеографічний дискурс проблем геосфери: матер. Міжнар. наук.-практ. інтернет-конф. 16 травня 2016 р. Мелітополь, 2016. С. 181-186.

7. Akdu Uğur, Gülmez Mustafa. Determining the Service Quality in Medical Tourism via Structural Equation Model. Journal of Current Researches on Social Sciences (JoCReSS). URL : www.stracademy.org/jocress ISSN: 2547-9644 Year:2017 Volume: 7 Issue: 2 doi: 10.26579/jocress7.2.31. (дата звернення: 10.07.2020).

8. Geva Ilan. The 20/50 theory in Medical Travel. Destination Health Magazine. Winter 2019. URL : www. destinationhealthmag.co.uk. (дата звернення: 10.07.2020).

9. The World Health Statistics 2019. World Health Organization. 2019. P. 67-71. URL: http: // www.who.int/ whosis/ whostat 2019/ en/index.html. (дата звернення: 19.07.2021). 


\section{References:}

1. Vakhovych, I.M. (2010) Faktory rozvytku rehional'noho rynku medychnoho turyzmu v rozvynenykh krayinakh svitu. [Factors of development of the regional market of medical tourism in the developed countries of the world]. URL : http://www.hitt-cis.net/wpcontent/uploads/2010/11/HITT/Ukraine. (accessed: 25.07.2020). [in Ukrainian].

2. Didenko, K.D., Zhuchenko, V.H. (2016) Medychnyy turyzm v Ukrayini: suchasnyy stan ta perspektyvy rozvytku. [Medical tourism in Ukraine: current state and prospects of development.]. Naukovyy visnyk Khersons'koho derzhavnoho universytetu. Seriya «Ekonomichni nauky». Issue 16. Part 4. P. 101-105. [in Ukrainian].

3. Sysoyenko Iryna. (2016) Yak medychnyy turyzm dopomozhe vryatuvaty ekonomiku Ukrayiny. [How medical tourism will help save Ukraine's economy]. URL : https://life.pravda.com.ua/columns/2016/04/12/210925/. (accessed: 18.07.2019). [in Ukrainian].

4. Udovychenko N. M., Mel'nychenko O. A. (2017). Medychnyy turyzm: sutnist' i vydy. [Medical tourism: essence and types]. Sotsial'no-ekonomichnyy i humanitarnyy vymiry rozvytku torhivli, hotel'no-restorannoho ta turystychnoho biznesu: zb. tez dop. mizhnar. nauk.-prakt. konf., 2324 bereznya 2017 r. Kharkiv: Vyd-vo KHTEI KNTEU. P. 185-186. [in Ukrainian].

5. Ukrayins'ka asotsiatsiya medychnoho turyzmu. (2021) [Ukrainian Association of Medical Tourism]. URL : http://uamt.org.ua/UA/. (accessed: 15.08.2021). [in Ukrainian].

6. Khrushch YU.M., Dioba K.I. (2016). Osoblyvosti rozvytku medychnoho turyzmu v sviti. [Features of the development of medical tourism in the world]. Istoryko-heohrafichnyy dyskurs problem heosfery: mater. Mizhnar. nauk.-prakt. internet-konf. 16 travnya 2016 r. Melitopol'.P. 181186. [in Ukrainian].

7. Akdu Uğur, Gülmez Mustafa. Determining the Service Quality in Medical Tourism via Structural Equation Model. Journal of Current Researches on Social Sciences (JoCReSS). URL : www.stracademy.org/jocress ISSN: 2547-9644 Year:2017 Volume: 7 Issue: 2 doi: 10.26579/jocress7.2.31. (accessed: 10.07.2020).

8. Geva Ilan. The 20/50 theory in Medical Travel. Destination Health Magazine. Winter 2019. URL : www. destinationhealthmag.co.uk. (accessed: 10.07.2020).

9. The World Health Statistics 2019. World Health Organization. P. 67-71. URL: http: // www.who.int/ whosis/ whostat 2019/ en/index.html. (accessed: 19.07.2021). 